\title{
Influence of the Sea Surface Temperature on the Stratification of Airmass and the Cumulus Activity over the East China Sea in the Baiu Season*
}

\author{
by \\ Kozo Ninomiya \\ Meteorological Research Institute, Tokyo
}

(Received May 28, 1974)

\begin{abstract}
Influence of the sea surface temperature on the stratification of airmass and cumulus activity over the East China Sea in the pre-summer rain season is studied on the basis of data of Experiment of Severe Rainstorms Research Project.

While the very warm water is distributed over the Kuroshio region in the southeastern part of the East China Sea, there is a cold water pool in the central part of the East China Sea.

The conditional unstable stratification of the subtropical airmass, which flows over the cold water pool, is modified into a very stable stratification. The airmass, which flows over the Kuroshio region, on the other hand, maintains its conditional instability.

The airmass modification over the cold water pool is simulated in the simple numerical experiment with equations of heat and moisture diffusion.

The influence of the sea temperature on the cumulus activity is examined by a statistical analysis of the radar echo distribution. The result of the analysis shows that cumulus convections are suppressed over the cold water pool.
\end{abstract}

\section{Introduction}

It is a well known fact that the stratification of an airmass depends greatly on the temperature of the underlaying sea surface.

The modification of the polar continental airmass and the cumulus generation over the warm sea in the winter season were studied extensively by many authors (e.g., Takahashi (1940), Burke (1945), Matsumoto and Ninomiya (1966 a and b), TsuchiYA and FuJITA (1967), NinomiYA (1968)). Airmass transformation occurs also in the summer season. Fog or stratus is frequently formed in the lower layer over the Yellow Sea, for example, when the subtropical airmass is cooled and stabilized over the cold water.

* This study is made as a part of Severe Rainstorms Research Project and partially supported through the Grant 4R013 from the Japan Society for the Promotion of Science as part of the Japan-U.S. Cooperative Science Program. 
Several authors discussed the airmass transformation in the summer season over the eastern part of the East China Sea in relation to the heavy rainfalls over the Kyushu District adjacent to the East China Sea. YAMADA (1962) pointed out in the statistical study of the echo generation that the cumulus activity tends to be suppressed over the cold watermass and organized cumulus frequently develops to the east of the warm sea current. OzAKI (1973) estimated the amount of heat and moisture exchanged between sea and air over the East China Sea in the summer season. YAMANAKA (1973) revealed the influence of the cold watermass on the lower tropospheric stratification by using the aerological data over the sea.

It would be useful to ascertain the features discussed in the articles mentioned above in a more systematic way for the understanding of the features of airmass transformation in the summer season and its relation to the rainfall.

\section{Sea surface temperature over the East China Sea and the large-scale weather situations in the Baiu season in 1969 and 1971}

Let us begin with the brief explanation on the sea surface temperature distribution over the East China Sea and adjacent sea areas in the Baiu season*.

Fig. 1 is the map of mean sea surface temperature for the 10-day period between 01 to 10 July 1969, which is reproduced from the Ten day Marine Report published

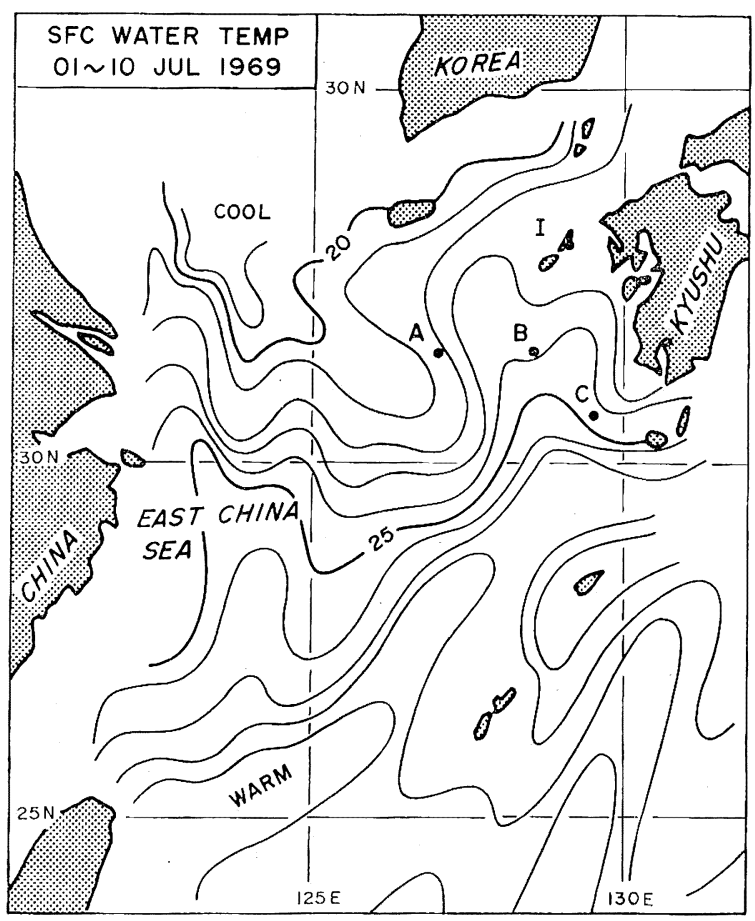

F1g. 1. Distribution of the sea surface temperature.

* The presummer rain season is called the "Baiu" season in Japan. 
from Nagasaki Marine Observatory. The north-bound warm sea current in the western Pacific Ocean flows into the East China Sea and flows along the Nansei Islands. It splits into two branches to the southwest of Kyushu. One branch flows back into the Pacific as the main Kuroshio current and the other branch penetrates into the Japan Sea to form the Tsushima current. The zone of very warm water is found over these currents. The sea surface temperature in the Kuroshio and the north-bound branch is about $29-27^{\circ} \mathrm{C}$ and $26-23^{\circ} \mathrm{C}$ respectively.

There is a predominant cold watermass in the Yellow Sea, which protrudes southward to form the cold water pool in the central part of the East China Sea. The characteristic features of sea surface temperature mentioned above are found not only in this particular period but in the Baiu season in general.

In the present study we will use the observation data obtained by the 2nd (1969) and 4th (1971) Experiment of Severe Rainstorms Research Project. The blackened circles $\mathrm{A}, \mathrm{B}$ and $\mathrm{C}$ in Fig. 1 indicate the fixed ship stations on which aerological observations were carried out and I indicates an aerological station on a small island (Fukue 47843). The period of the observation and the name of the observation ships are listed in Table 1.

Table 1. Observation ships on which aerological observations were carried out.

\begin{tabular}{c|c|c|c}
\hline \hline position & $31^{\circ} 30^{\prime} \mathrm{N}, 127^{\circ} \mathrm{E}$ & $31^{\circ} 30^{\prime} \mathrm{N}, 128^{\circ} 30^{\prime} \mathrm{E}$ & $30^{\circ} 40^{\prime}, \begin{array}{c}\mathrm{C} \\
129^{\circ} 30^{\prime} \mathrm{E}\end{array}$ \\
\hline \multirow{2}{*}{1969} & $\begin{array}{c}\text { Hakuho-maru } \\
(3,200 \text { ton }) \\
\text { Ryofu-maru } \\
(1,600 \text { ton })\end{array}$ & $\begin{array}{c}\text { Ryofu-maru } \\
(1,600 \text { ton })\end{array}$ & $\begin{array}{c}\text { Seifu-maru } \\
(360 \text { ton })\end{array}$ \\
\hline
\end{tabular}

We will next explain the large-scale weather sitaution in the analyzed period in 1969 and 1971. The situation in the 2nd Experiment (03-10 July, 1969) is characterized by the active Baiu front* which persistently lay over the East China Sea.
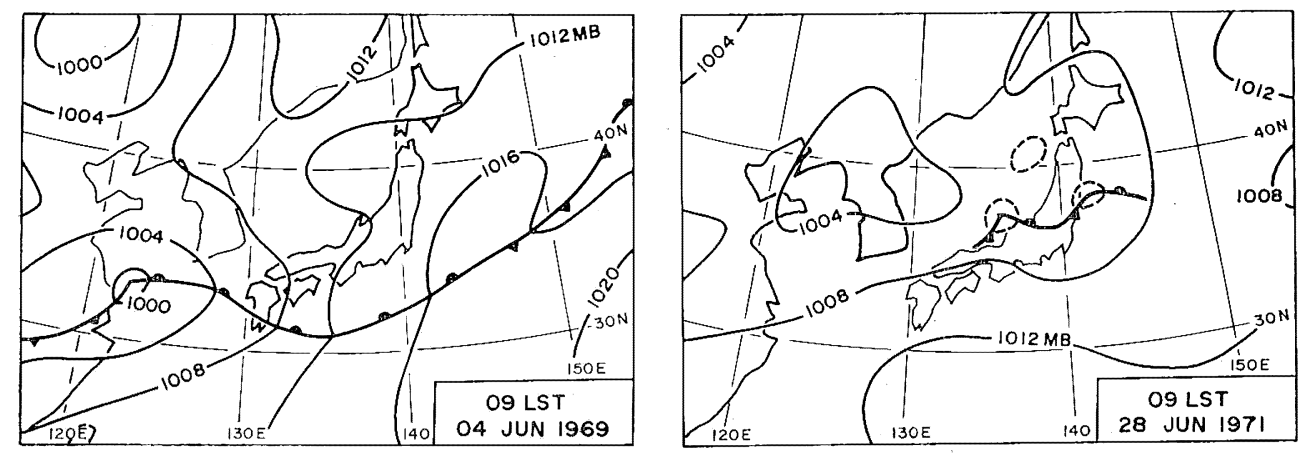

Fig. 2. Surface map at 09 LST, 04 July 1969 (Left) and 09 LST, 28 June 1971 (right).

* The stationary front between the subtropical airmass and the midlatitudinal airmass in the Baiu season is called the Baiu front. 
Medium-scale cyclones frequently passed along the front and brought heavy rainfall over Kyushu (see MAtsumoto et al. 1971). The surface map at 09 LST 04 July 1969 in Fig. 2A shows the typical situation during this period. The situations in the 4th Experiment (25 June-02 July 1971) is, on the contrary, characterized by continuation of fine weather as the Baiu front lay to the north of the East China Sea. The typical situation during this period will be seen in Fig. 2B (i.e., the surface map at 09 LST 28 June 1971).

It will be necessary to make note of the air temperature. Since the southwesterly wind predominates over the East China Sea in the Baiu season, a very moist and warm subtropical airmass is advected toward this region. The surface air temperature is on the average, a little higher than the sea surface temperature even over the Kuroshio region. The former is considerably higher than the latter over the cold water pool.

\section{Comparison between the radiosonde and dropsonde observations}

Since we intend to study the stratification in the lower layer over the sea, we should ascertain whether the aerological data obtained on the ship indicate the true temperature over the sea. Under the condition of strong insolation the body of the ship is heated and thus the data obtained on the ship may indicate the higher temperatures in the lowermost layer. It will be necessary, therefore, to compare the radiosonde data with those of dropsonde.

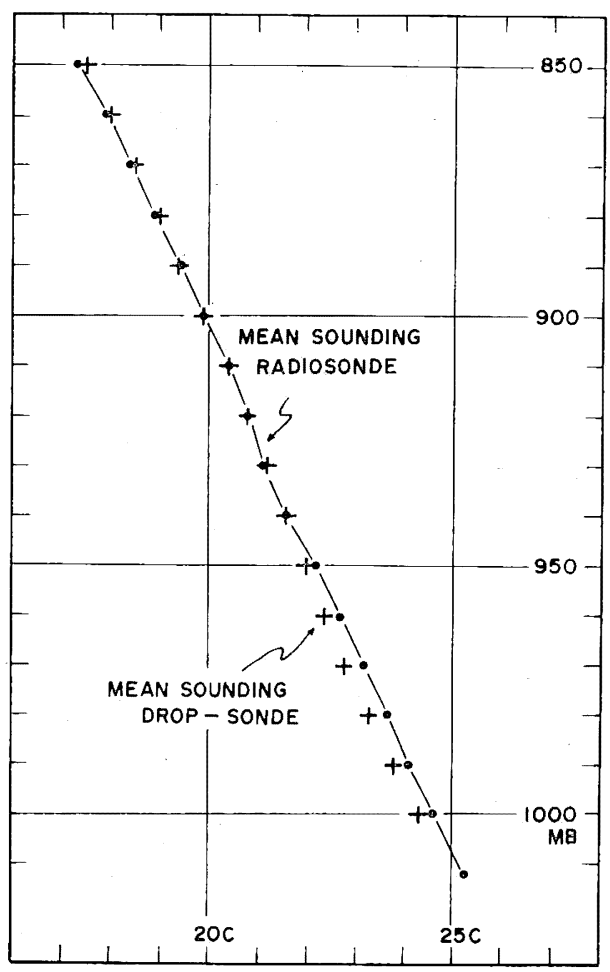

Fig. 3. Mean temperature sounding by radiosonde and dropsonde observations. 
Among the 17 dropsonde observations made in the 4th Experiment, 4 observations* (i.e., 25, 26, 27 and 30 June 1971) were made in the vicinity of the ship station B (see Fig. 1 and Table 1) in the morning. The averaged sounding obtained from these dropsonde observations and that from the 4 corresponding radiosonde observations at 09 LST on the ship station are compared in Fig. 3. Although the two coincide well with each other in layers above $950 \mathrm{mb}$, the latter shows considerably higher temperatures as compared with the former in layers below $960 \mathrm{mb}^{* *}$. Since the ascension rate of the radiosonde is about $400 \mathrm{~m} / \mathrm{min}$, Fig. 3 suggests that the heated ship body would affect the temperature sounding in the first one minute after the release of the radiosonde if the sky is clear.

As the difference is about $0.5^{\circ} \mathrm{C}$ in the morning, larger differences may occur around noon. The vertical distribution of the amplitude of the diurnal variation of temperature over the island station I (see Fig. 13) would suggest that the maximum error in temperature sounding on the observation ship is not larger than $1^{\circ} \mathrm{C}$.

\section{Stratification of the airmass over the East China Sea}

The aerological observations were carried out on the fixed ship stations A, B and $\mathrm{C}$ in the 2nd Experiment (see Fig. 1 and Table 1). As seen in Fig. 1, stations A. B and $\mathrm{C}$ are located on the cold water pool, the northbound branch of the warm sea current and the Kuroshio respectively.

The mean situation during the one week period of the Experiment will be examined first. The mean temperature soundings at A, B and $\mathrm{C}$ are presented in Fig. 4, where the height is expressed $P_{\mathrm{spc}}-P(\mathrm{mb})$ in the abscissa. It is evident that the sea surface temperature greatly influences the airmass stratification in the lowermost layer below $500 \mathrm{~m}$. The mean lapse rate of temperature, $-\partial T / \partial p$, at $\mathrm{A}$ and $\mathrm{C}$ are compared in

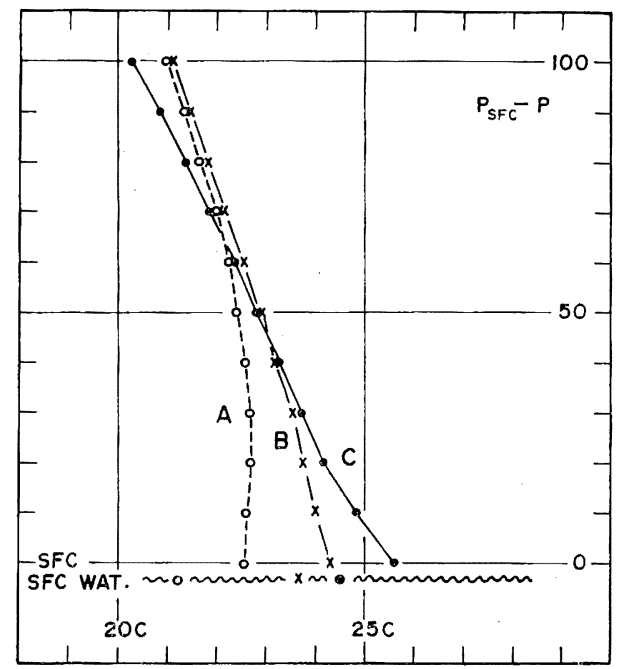

Fig. 4. Mean temperature sounding at the ship stations A, B and C (see Fig. 1).

\footnotetext{
* These were made under a clear sky.

** The number of samples is too small, however, to make conclusive discussion.
} 


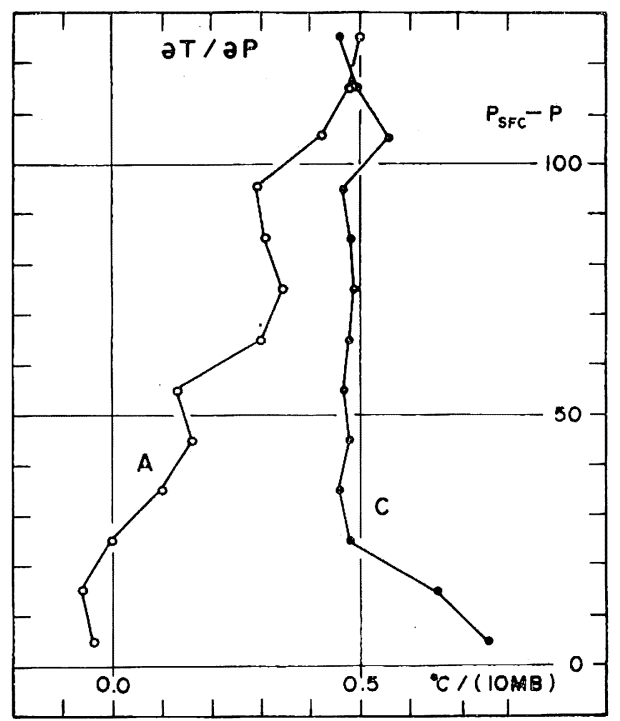

Fig. 5. Mean temperature lapse rate at $\mathrm{A}$ and $\mathrm{C}$.

Fig. 5. The lapse rate at $\mathrm{C}$ (i.e., over the Kuroshio) is about $0.5^{\circ} \mathrm{C} /(10 \mathrm{mb})$ throughout the lower tropsophere except the lowermost layer below $300 \mathrm{~m}$ where it is as large as about $0.8^{\circ} \mathrm{C} /(10 \mathrm{mb})$. The mean lapse rate at $\mathrm{A}$ (i.e., over the cold water pool) is very small and temperature inversion is seen in the lowermost layer. In a climatological study on the stratification, MAGATA and NishidA (1971) stated that the lapse rate in the lower troposphere in the Baiu season is about $0.5^{\circ} \mathrm{C} /(10 \mathrm{mb})$ in western Japan. The stratification in the lower layer in Fig. 5, therefore, must be the manifestation of the airmass transformation.

There is, of course, temporal variation in the temperature field in the lower layer associated with the change in the synoptic situations and therefore the stratification in each day may differ from the averaged one shown in Figs. 4 and 5. We will next investigate the stratification under two particular synoptic situations.

One is the case of relatively cool air advected over warm water. Although no strong cold air outbreak occurs in the Baiu season, relatively cool midlatitudinal airmass is advected in the rear of the synoptic scale cyclone. The selected data for this siuation are the radiosonde observations at 15 LST 03, 03 LST 04 and 09 LST 04 July 1969 at station C. The averaged sounding of these three cases is shown in Fig. 6 as indicated by "cool air over warm water".

Another is the case of very warm air advected over the cold water pool. Sometimes the subtropical airmass invades into the northern East China Sea accompanied by the southwesterly winds. The selected radiosonde data for this category are the data at 15 LST 05 and 21 LST 07 July 1969 at the station A. The averaged sounding of these two observations is also shown in Fig. 6 as indicated by "warm air over cool water".

The vertical distributions of the lapse rate $-\partial T / \partial p$ obtained from these two averaged soundings in Fig. 6 are presented in Fig. 7. The stratification of the "cool air 


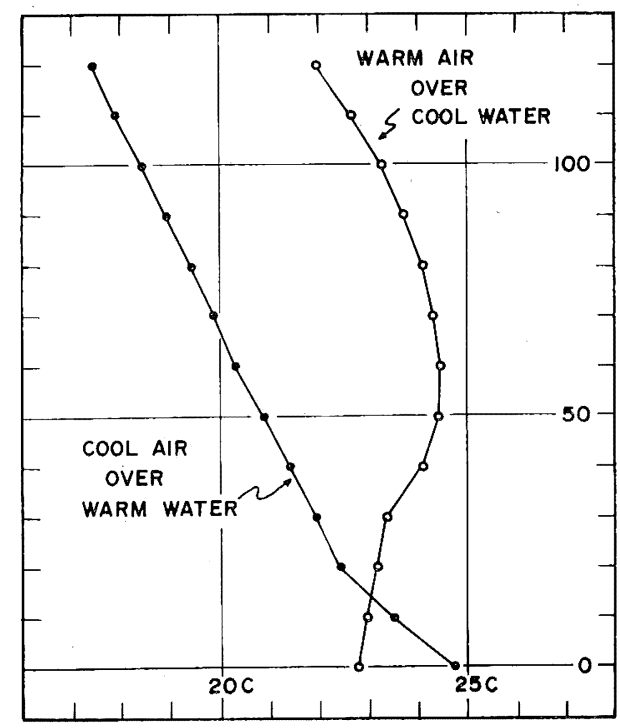

Fig. 6. Composite temperature sounding for the cases of "warm air over cool water" and "cool air over warm water".

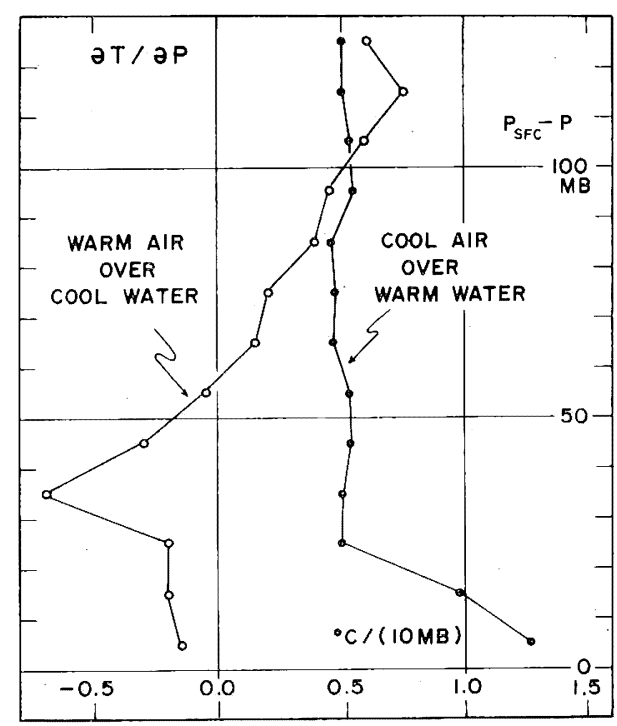

Fig. 7. Composite temperature lapse rate for the cases shown in Fig. 6 .

over warm water" is characterized by the superadiabatic lapse rate in the layer below $200 \mathrm{~m}$. This resembles the situation of the modified polar continental airmass in the winter season over the warm sea (c.f. KUвотA (1972)), although the layer of the superadiabatic lapse rate is considerably thin as compared with that in the winter cases. The situation of the "warm air over cool water" is characterized by a thick layer of temperature invasion. 
It will be concluded from the discussions in the present section that the cold water pool in the East China Sea works to stabilize the airmass stratification in the Baiu season. Since the water is not warmer on the average than the air even in the Kuroshio region in the Baiu season, the vertical instability of the airmass would not be enhanced except in the case of cool airmass advection over the Kuroshio region.

\section{Simple numerical experiment of airmass transformation over the cold water pool}

Since the airmass transformation over the cold water pool seems to be due to vertical eddy diffusion, the process of the transformation will be well simulated by the equations of heat and moisture diffusion. The numerical experiment of the transformation in the present paper is made by adopting the method used by AsAI (1965) in his study on the cold air transformation over the warm sea. As he intended to see the change along the airmass trajectory, he converted the time change into change in distance by assuming a steady movement of the airmass. The airmass movement over the East China Sea in the Baiu season is not so simple as that over the Japan Sea in winter. Therefore, we will calculate the time change of temperature and moisture of the warm airmass put on the cold water surface of $21^{\circ} \mathrm{C}$.

The equations which govern the process are

$$
\begin{aligned}
& \frac{\partial \theta}{\partial t}=-\frac{\partial}{\partial z} F_{\theta}+Q \\
& \frac{\partial q}{\partial t}=-\frac{\partial}{\partial z} F_{q}-M
\end{aligned}
$$

and

$$
\frac{\partial m}{\partial t}=M
$$

where $\theta, q, m, Q$ and $M$ are the potential temperature, mixing ratio of water vapor, that of liquid water, rate of heating due to condensation and the rate of the condensation respectively. The flux of the heat and the moisture $F_{0}$ and $F_{q}$ in the atmospheric layer are

$$
F_{\theta}=-K \frac{\partial}{\partial z} \theta \text { and } \quad F_{q}=-K \frac{\partial}{\partial z} q
$$

and these at the surface are given as

$$
F_{0}=C U\left(\theta_{1}-\theta_{2}\right) \text { and } F_{q}=C U\left(q_{1}-q_{2}\right)
$$

where subscripts and 1 and 2 indicate the values at the sea surface and the first level of the atmosphere.

For the numerical experiment, the atmospheric layer with a depth of $2,000 \mathrm{~m}$ is divided into 100 sublayers with a depth of $20 \mathrm{~m}$. The method of time integration is same as used by ASAI (1965) and will bevery briefly noted in the Appendix.

The value of 0.002 is given for $C$ in eqs. (6) and (7) by referring the papers of DEACON et al. (1956) and JACOBS (1942). The surface wind speed of $5 \mathrm{~m} \cdot \mathrm{sec}^{-1}$ is given for the value of $U$ in eqs. (6) and (7) in the present experiment.

The coefficient of eddy exchange $K$ should be assumed to depend on the static stability (and therefore time) as suggested by FISHER and KAPLAN (1963) or ASAI

\footnotetext{
* The sensible heat and the moisture exchanges are $\rho C_{p} C U\left(\theta_{1}-\theta_{2}\right)$ and $\rho C U\left(q_{1}-q_{2}\right)$ respectively.
} 
(1965). Here we will adopt the same expression of $K$ as that used by AsaI (1965), i.e.,

$$
K=K^{*} /\left(1+\alpha-\frac{\partial \theta}{\partial z}\right)
$$

where $K^{*}$ is the exchange coefficient under adiabatic conditions and is chosen here to be $10 \mathrm{~m}^{2} \cdot \mathrm{sec}^{-1}$. The experiments are made with various values of $\alpha$.

The mean temperature and moisture soundings obtained at station $C$ (i.e., over the Kuroshio region) are considered to represent the stratification of the subtropical airmass and therefore adopted as the initial values of $\theta$ and $q$ for the experiments. Since the horizontal extension of the cold water pool is $100-200 \mathrm{~km}$ and the surface wind is about $5 \mathrm{~m} \cdot \mathrm{sec}^{-1}$, the air mass will stay over there for about 5-10 hours, and so we integrate these equations for 10 hours.

Examples of the results of experiments are shown in Figs. 8 and 9, where the initial temperature* distribution is shown by the heavy line indicated by $C$. The small open circles in these figures indicate the observed mean sounding at the station A (i.e., over the cold water pool). The results of experiments show that if $\alpha$ is $100 \mathrm{~m} \cdot \mathrm{C}^{-1}$, the modification reaches to a higher level and if $\alpha$ is $500 \mathrm{~m} \cdot \mathrm{C}^{-1}$ the modification is con-

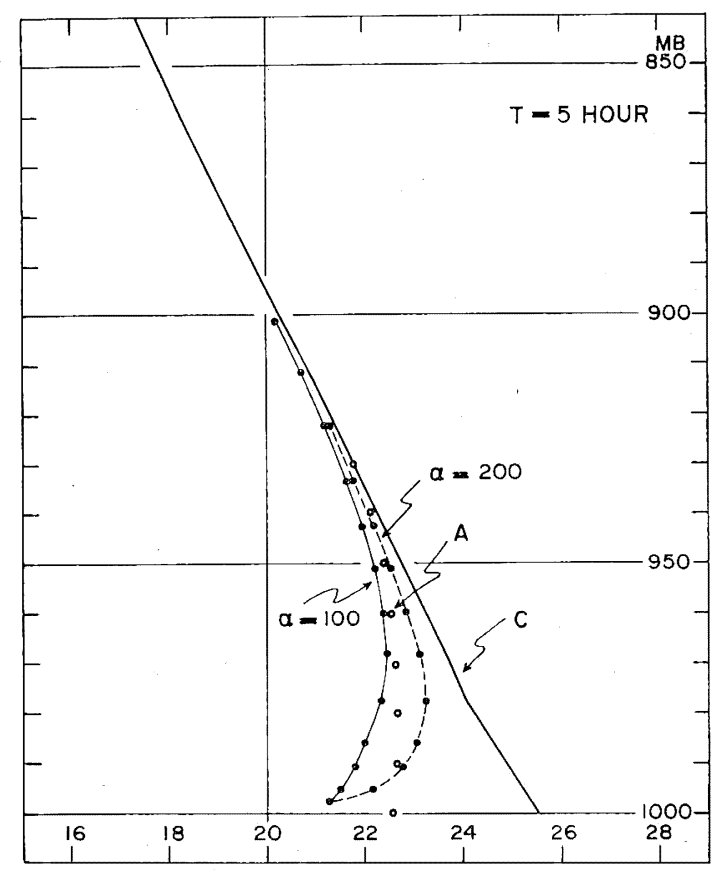

Fig. 8. Vertical profiles of temperature obtained from the numerical experiment with the various valus of $\alpha$ at $T=5$ hour. The thick line and the open circles show the initial profile and observed profile over the cold water pool.

* The initial moisture distribution is not shown in the figures. The relative humidity at the initial state is about $85-95 \%$. 


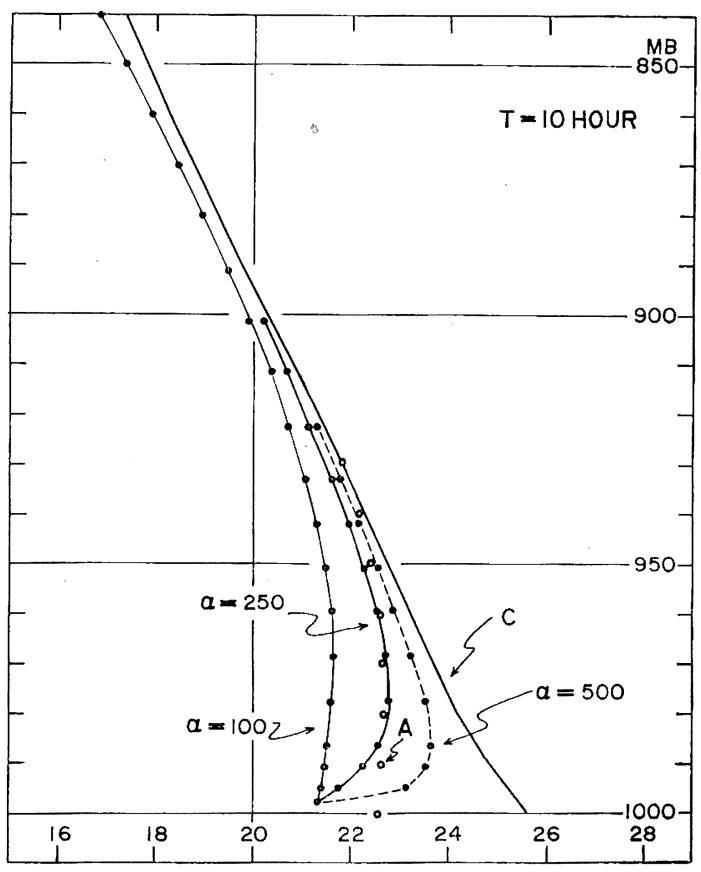

Fig. 9. Same as Fig. 8 but at 10 hour.

fined within the lowermost layer only. The resulting temperature distribution in the experiment with $\alpha$ of $100-250 \mathrm{~m} \cdot \mathrm{C}^{-1}$ well coincides with the observed distribution over the cold water pool. Condensation occurs in the lower layer for all cases and the amount of condensation is about $3 \mathrm{~mm} /(10$ hour $)$ for the experiment with $\alpha$ of $250 \mathrm{~m} \cdot \mathrm{C}^{-1}$.

\section{Influence of the sea surface temperature on the cumulus generation}

The fact that the lower tropspheric stratification is greatly controlled by the sea surface temperature suggests that the cumulus formation also may be controlled by the sea temperature. In the present section we will ascertain this supposition by using the radar observation data.

The area under cosideration was covered by the observation range of the meteorological radar of Ryofu-maru at point B (see Fig. 1) during the 2nd Experiment. From 168 sheets of PPI radar picture hourly obtained, echo amounts were read for every section bounded by concentric circles at $50 \mathrm{~km}$ intervals and radii at 15 degree intervals as shown in Fig. 10.

The echo amount obtained in each section on each PPI picture is expressed as $e(i, j, t)$ where $i(=1,2,3), j(=1,2, \ldots 24)$ and $t(=1,2, \ldots 168)$ indicate the concentric radius, azimuth and the observation time respectively. We next calculate the average echo amount over the analyzed period (i.e., 168 hours) for each $\operatorname{section}, m(i, j)$, as

$$
m(i, j)=\frac{1}{168} \sum_{\iota} e(i, j, t)
$$




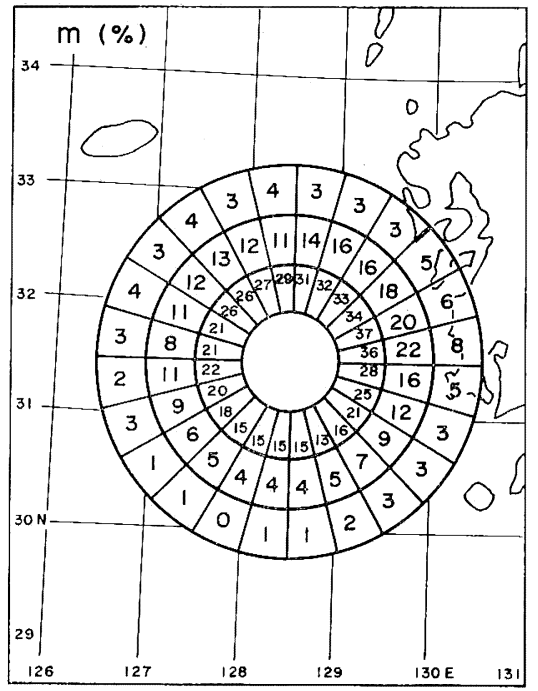

Fig. 10. Distribution of mean echo amount $(m)$.

and present the values obtained in Fig. 10. Since the isoecho display device is not used for PPI observation, the observed echo amount decreases with distance as seen in Fig. 10. Consequently some correction would be required for the investigation of the occurrence frequency of echoes. In order to do this, we calculate the mean echo amount $\bar{m}(\imath)$ by averaging echo amount over all sections at equidistance as

$$
\bar{m}(i)=\frac{1}{24} \sum_{j} m(i, j)
$$

The relative mean echo amount is then defined for every section by dividing $m(i, j)$

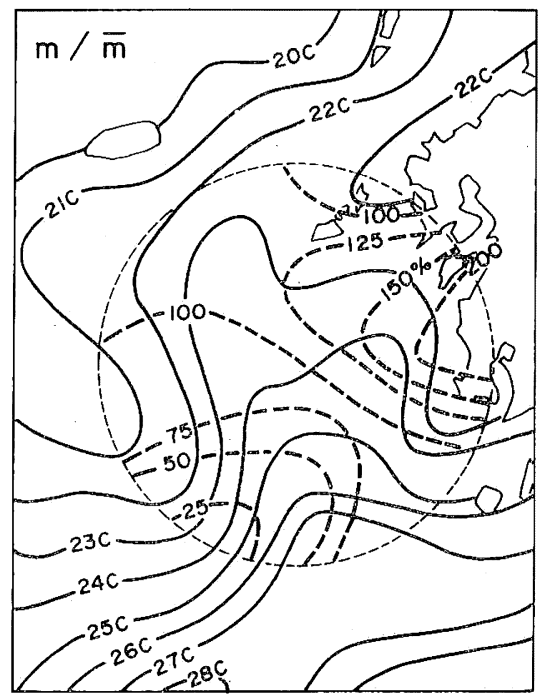

Fig. 11. Distribution of $m / \bar{m}$ ("relative echo amount") and the sea surface temperature. 
by $\bar{m}(i)$. This convenient procedure would eliminate the effect of attenuation due to distance. The distribution of $m(i, j) / \bar{m}(i)$ is compared with that of sea surface temperature in Fig. 11.

We also calculate the standard deviation of echo amount in each section, $\sigma^{2}(i, j)$ from $e(i, j, t)^{*}$, in order to investigate the time variation of the echo. The effect of attenuation due to distance is then eliminated by dividing $\sigma^{2}(i, j)$ by $\bar{\sigma}^{2}(i)$ where $\bar{\sigma}^{2}(i)$ is $\frac{1}{24} \sum_{j} \sigma^{2}(i, j)$. Fig. 12 shows the distribution of $\sigma^{2}(i, i) / \bar{\sigma}(i)$ and the surface water temperature.

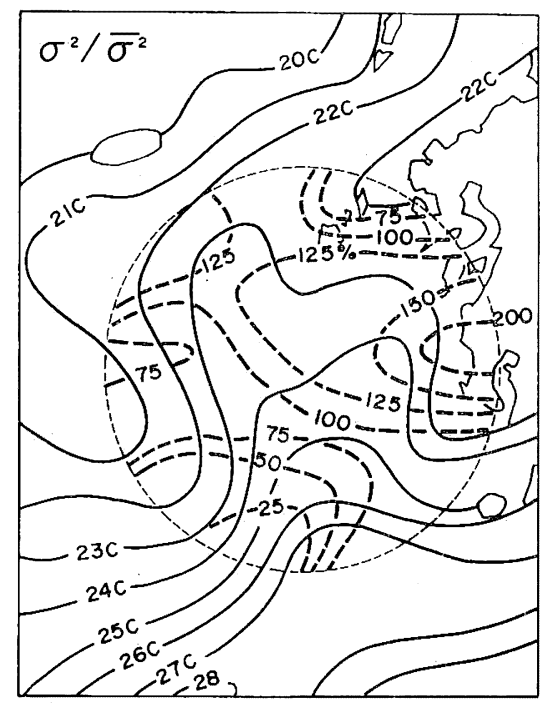

Fig. 12. Distribution of $\sigma^{2} / \bar{\sigma}^{2}$ ("relative standard deviation") and the sea surface temperature.

We should be very careful in interpreting these figures, because the cumulus activity may be controlled by both the large-scale atmospheric disturbances and sea surface temperature. The small values of $m / \bar{m}$ or $\sigma^{2} / \bar{\sigma}^{2}$ found in the northern and the southern area of the investigated domain will be explained by the fact that these areas are outside the Baiu frontal zone. We will now examine the situation within the frontal zone which lay east and west through southern Kyushu. The values of $m / \bar{m}$ Tand $\sigma^{2} / \bar{\sigma}^{2}$ are very large in the eastern area of the domain, where the sea water is very warm, while these values are very small in the western area where the sea water is remarkably cold.

It is suggested from Figs. 4, 5, and 11 that the cumulus activity within the frontal zone is suppressed over the cold water pool because the airmass stratification is

$$
\sigma^{2}(i, j)=\frac{1}{168} \sum_{i}[e(i, j, t)-m(i, j)]^{2}
$$


remarkably stabilized from the modification over the cold water*.

The large amount of $m / \bar{m}$ or $\sigma^{2} / \bar{\sigma}^{2}$ (in Fig. 12) over the warm water does not necessarily mean, however, that the echoes are enhanced from airmass modification over the warm sea because the temperature of the air is somewhat higher than that of the sea as was already mentioned in the previous section. It should also be noted that the warm water mass does not always enhance the cumulus activity by itself. For example, no intense rainfall or active echo is observed over the warm water areas during the period of the 4th Experiment because the large-scale atmopsheric situations were unfavourable to the cumulus activity. The reason why the echo amount is large over the warm sea during the period of the 2nd Experiment would be that cumulus activity is not suppressed over the warm sea provided the large-scale situation is favourable to it.

\section{Diurnal variation of the air temperature in the lower layer on a small island}

It is sometimes found in the summer season that convective clouds develop in the daytime over a heated island. As the aerological observations at Fukue** (see the station indicated by I in Fig. 1) during the 4th Experiment were made fine weather, these data would be useful in studying the diurnal variation of temperature over a small island.

The diurnal variation of air temperature at the surface and levels 20,40,60 and $80 \mathrm{mb}$ above the surface are shown in Fig. 13. The maximum and minimum temperature occur at $15 \mathrm{LST}$ and $00-03$ LST respectively. The right side figure in Fig. 13 represents the vertical distribution of the difference between the maximum and minimum temperatures $T_{\max }-T_{\min }$. The amplitude of the diurnal variation decreases rapidly with height, and, therefore, the diurnal variation of the vertical stability is quite large in the lower layers. The vertical distributions of the temperature lapse rate at $00 \mathrm{LST}$ and $12 \mathrm{LST}$ over the island are presented in Fig. 14. (The mean lapse rate at the ship station $B$ is also presented in Fig. 14.) As seen in these figures, the diurnal variation over a small island is confined in the lower layer below $400-500 \mathrm{~m}$. The amplitude of the variation over this island is considerably smaller than the amplitude shown in the textbook written by HALTINER et al. (1957). This would be due to the fact that the areal dimension of this island is very small.

The diurnal variation of the vertical stability would influence the convective clouds over the island. The diurnal variation of the convective cloud amount over Fukue is

* There would be different interpretations of the echo distribution in Fig. 11. The large amount of echo over the eastern part may be due to the development of medium-scale disturbances during the eastward propagation (cf. MAтSUMото et al. 1971).

It would be criticized that the time-scale of cumulus development is shorter than that of the airmass stabilization. The dimensions of the coldwater pool may be too small to suppress the cumulus clouds effectively. It would be also said that the cold water pool does not always control the cumulus activity if there occurs the convergence of the very moist subtropical airmass in the layer above $950 \mathrm{mb}$ as the stabilization is confined within the lowermost layer.

Although it is difficult to answer these criticisms conclusively, the stabilization of the airmass stratification over the cold water pool is certainly one of the unfavorable conditions for cumulus formation.

** The area of the island is about $160 \mathrm{~km}^{2}$. 


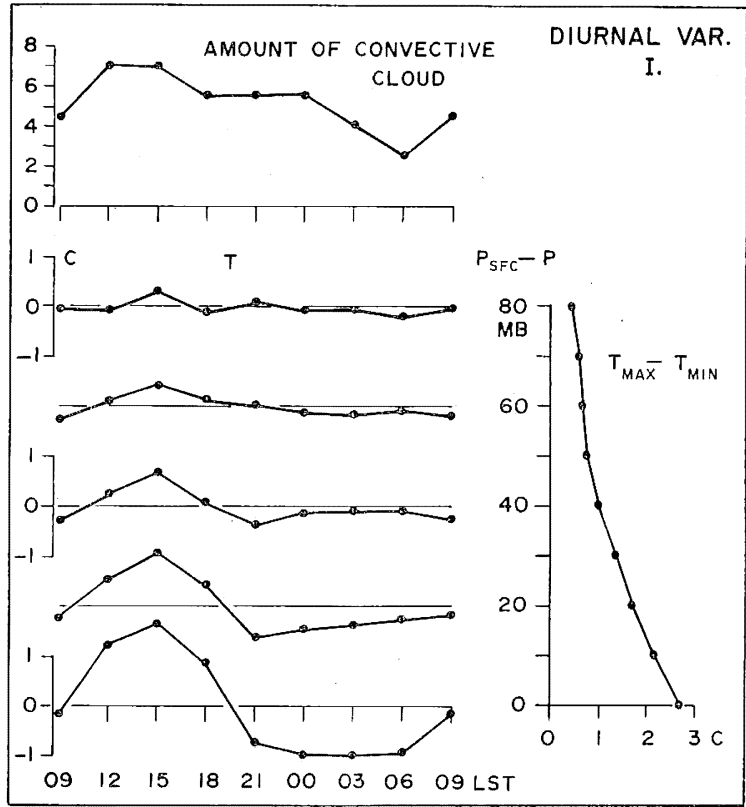

Fig. 13. Diurnal variation of temperature and the amount of convective cloud over an island.

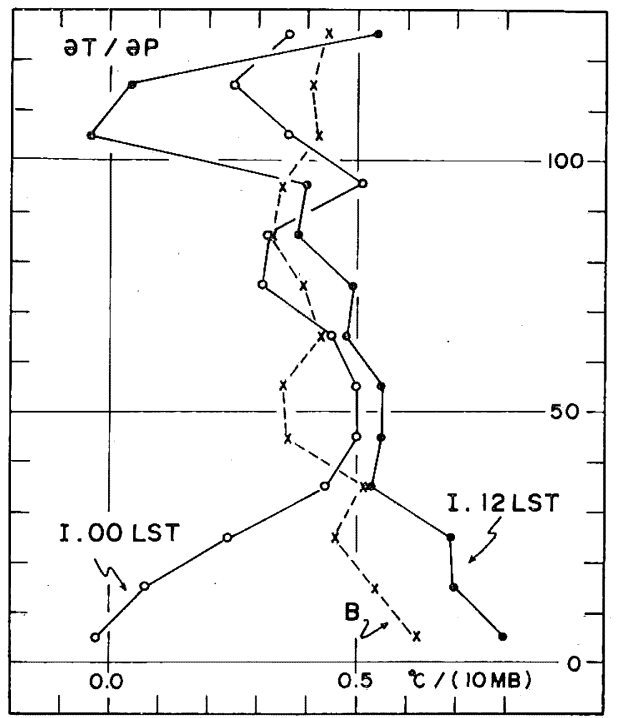

Fig. 14. Temperature lapse rate at 00 LST and 12 LST over an island and mean lapse rate over ship station $B$.

presented in the upper part of Fig. 13. The maximum and the minimum amount are seen at 12-15 LST and 06 LST respectively. Some large cumuli developed in the deytime over the island. It should be noted, however, that no intense precipitation was 
recorded. It would be said that the heating of the island by insolation does not control, by itself, the intense precipitation in the Baiu season.

\section{Concluding remarks}

Several observational studies have suggested that echo generations and heavy rainfalls over the sea area adjacent to Kyushu are controlled by the sea surface temperature. In the present report, we have studied the relations between the sea surface temperature, airmass stratification and the echo distribution over the eastern part of the East China Sea by using data from the 2nd (1969) and 4th (1971) Experiments of Severe Rainstorms Research Project.

The results have revealed that the airmass stratification is remarkably stabilized from the modification over the cold water pool and, consequently, the convective activity is suppressed over there.

Under a certain large-scale situation favorable to the development of cumulus convections, such as the situation of the active Baiu front, a large amount of radar echo is found over the area of warm sea currents. This does not necessarily mean, however, that the cumuls activity is enhanced from the airmass modification over the warm sea because the air temperature, under the situation mentioned above, is somewhat higher than the sea temperature even in the Kuroshio region. The reason why the echo amount is large over the warm see would be that the cumulus activity is not suppressed over the warm sea if the large-scale situation is favorable to the cumulus activity.

Acknowledgements-The author expresses his hearty thank to participators of Experiment of the Heavy Rainstorms Research Project who carried out the extensive observations and prepared the large amount of of data. He would like to express his gratitude to Misses T. Akiyama and H. Imai for their various assistance.

\section{Appendix}

The procedure for solving the set of eqs. (1)-(3) is quite the same as that used by ASAI (1965) and will be very briefly described here. The values of $\theta, q$ and $m$ are computed tentatively from

$$
\partial \theta / \partial t=-(\partial / \partial z) F_{\theta}, \partial q / \partial t=-(\partial / \partial z) F_{q}
$$

and $\partial m / \partial t=0$ respectively. These tentatively obtained values of $\theta, q, m$ and the saturated mixing ratio are denoted as $\theta^{*}, q^{*}, m^{*}$ and $q_{s}^{*}$ respectively. The values of $\theta, q$ and $m$ are then obtained from $\theta^{*}, q^{*}, m^{*}$ and $q_{s}^{*}$ according to the condition as described below:

$$
\begin{aligned}
& \text { (A) } \quad q^{*}-q_{s}^{*} \equiv \delta M>0 \\
& \theta=\theta^{*}+B r_{1} \delta M \\
& q=q^{*}-r_{1} \delta M \\
& m=m^{*}+r_{1} \delta M \\
& \text { (B-1) } \quad q^{*}-q_{s}^{*} \equiv \delta M<0, m^{*}>0 \text { and } m^{*}+r, \delta M \geq 0 \\
& \theta=\theta^{*}+B r_{1} \delta M \\
& q=q^{*}-r_{1} \delta M
\end{aligned}
$$




$$
\begin{aligned}
m & =m^{*}+r_{1} \delta M \\
(\mathrm{~B}-2) \quad q^{*}-q_{s} & \equiv \delta M<0, m^{*}>0 \text { and } m^{*}+r_{1} \delta M<0 \\
\theta & =\theta^{*}-B m^{*} \\
q & =q^{*}+m^{*} \\
m & =0 \\
q^{*}-q_{s} & \equiv \delta M<0 \text { and } m^{*}=0 \\
\theta & =\theta^{*} \\
q & =q^{*} \\
m & =m^{*}=0
\end{aligned}
$$

where $B$ and $r_{1}$ are defined as

$$
\left(\frac{L}{C_{p}}\right)\left(\frac{p_{0}}{p}\right)^{\kappa} \text { and } \frac{1}{\left[1+\frac{L^{2}}{C_{p} R_{v}}\left(\frac{p_{0}}{p}\right)^{2 \kappa} \frac{q_{s}}{\theta^{2}}\right]}
$$

respectively.

\section{References}

AsAI, T., 1965: A numerical study of the airmass transformation over the Japan Sea in winter. J. Met. Soc. Japan, 43, 1-15.

BURKE, C. J., 1945: Transformation of polar continental air to polar maritime air. J. Met., 2, 94-112.

Deacon, E. L., P. A. Sheppard and E. K. Webb., 1956: Wind profiles over the sea and the drag at sea surface. Australian J. Phys, 9, 511-541.

Fisher, E. L. and P. CAPLAN, 1963: An experiment in numerical prediction of fog and stratus. J. Atmos. Sci., 20, 425-437.

Haltiner, G. J. and F. L. Martin, 1957: Dynamical and Physical Meteorology. $470 \mathrm{pp}$ McGraw Hill Book, New York.

JACOBS, W. C., 1942: On the energy exchange between sea and atmosphere. J. Marine Res., 5, 37-66.

Kubota, I., 1972: Vertical stability and precipitation over the Japan Sae. (in Japanese) Tenki, 19, 391-398.

Magata, M. and K. Nishida, 1971: Statistical properties of the atmosphere. (in Japanese) Tenki, 18, 399-406.

Matsumoto, S. and K. NinomiYa, 1966: Some aspects of the cloud formation and its relation to the heat and moisture supply from the Japan Sea surface under a weak winter monsoon situation. J. Met. Soc. Japan, 44, 60-75. Japan Sea under a winter monsoon situation as revealed by dropsonde and aerial photographic observation. Pap. Met. Geophys., 17, 51-64.

Matsumoto, S., K. NinomiYa and S. Yoshizumi, 1971: Characteristic features of Baiu Front associated with heavy rainfall. J. Met. Soc. Japan, 49, 267-281.

NinomiYa, K., 1968: Cumulus group activivity over the Japan Sea in wintertime in relation to the water vapor convergence in subcloud layer. J. Met. Soc. Japan, 46, 373-388.

OZAKI, K., 1973: Estimation of the temperature change in the process of air-sea interaction. Memoirs of Fukuoka Meteorological Observatory (in Japanese) No. 28, 201-209.

TAKahashi, K., 1940: On the transformation of the cold and dry airmass by traveling over warm sea. J. Met. Soc. Japan, 18, 77-80.

TsuchiYA, K. and T. FuJITA, 1967: A satellite meteorological study of evaporation and cloud formation over the western Pacific under the influence of the winter monsoon. 
1974 Influence of the Sea Temperature on the Stratification in Lower Layers

J. Met. Soc. Japan, 45, 232-250.

YAMADA, S. 1962: Characteristic features of line echo. (in Japanese) Memorirs of Fukuoka Meteorological Observatory, No. 18, 36-52.

YAMANAKA, R. 1973: Generation and development of disturbances over the sea area to the west of Kyushu in the Baiu season. (in Japanese) Memoirs of Fukuoka Meteorological Observatory, No. 28, 176-200.

\section{梅雨期東支那海域の海水温分布の気団の成層 \\ およびエコー分布におよぼす影響}

二宮 洸 三

梅雨期東支那海域の海水温分布, 気団の成層およびェコー分布の間の関係を, 第 2 次 (1969) 抽よび第 4 次 (1971) 梅雨末期集中豪雨特別観測の資料によって明らか沉するのが，この報告の目的である。

冷水域上では気団は冷却され，その成層は著しく安定化される。この過程は簡単な数值実験でるよく再現 される。この安定化のため冷水域ではエコーの発達は著しく抑制される。

一方総観的条件が大雨の発生に適すれば (1969年の如く梅雨前線が停滞して) 暖水域ではエコー量が多 い。しかし，これは気団変質の結果，成層が不安定化してェューの発達が強化されるからだとは言えない。 このような総観状況下では, 䁔水域上に执いてすら, 気温は海水温より高く，気層の不安定化は加速されな いからである。上記した大きなエコー量は, 総観状況が積雲対流の発達に適しているならば, 暖水域では, その発達が抑制されないからであると説明され得よう。

また，もし総観状況が積雲対流の発達に適しなければ (1971年のごとく), 暖水域上でもェコーの発達は みられない。

なお，梅雨期にも軽度の寒気吹出がみられるが（これは大雨の発生する状態ではないが）この場合には䁔 水域では, “気団変質”（冬期のような）が㧊こり，最下層では，成層の不安定化がひきおこされることもあ る。 